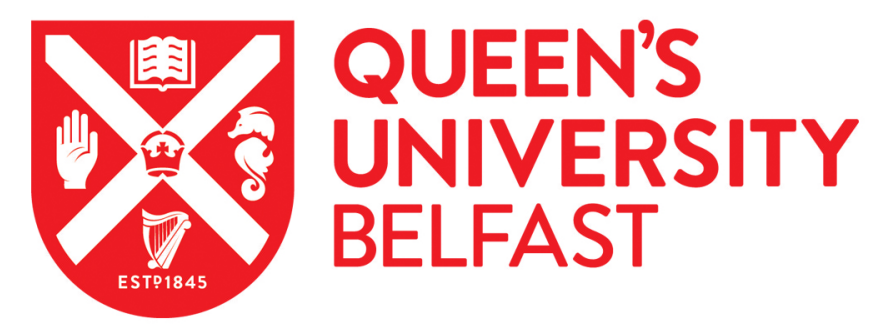

\title{
Surface plasmon resonance biosensing: Approaches for screening and characterising antibodies for food diagnostics
}

Yakes, B. J., Buijs, J., Elliott, C. T., \& Campbell, K. (2016). Surface plasmon resonance biosensing: Approaches for screening and characterising antibodies for food diagnostics. Talanta, 156-157, 55-63.

https://doi.org/10.1016/j.talanta.2016.05.008

\section{Published in:}

Talanta

\section{Document Version:}

Peer reviewed version

Queen's University Belfast - Research Portal:

Link to publication record in Queen's University Belfast Research Portal

\author{
Publisher rights \\ (C) 2016 Elsevier \\ This is an open access article published under a Creative Commons Attribution-NonCommercial-NoDerivs License \\ (https://creativecommons.org/licenses/by-nc-nd/4.0/), which permits distribution and reproduction for non-commercial purposes, provided the \\ author and source are cited.
}

\section{General rights}

Copyright for the publications made accessible via the Queen's University Belfast Research Portal is retained by the author(s) and / or other copyright owners and it is a condition of accessing these publications that users recognise and abide by the legal requirements associated with these rights.

Take down policy

The Research Portal is Queen's institutional repository that provides access to Queen's research output. Every effort has been made to ensure that content in the Research Portal does not infringe any person's rights, or applicable UK laws. If you discover content in the Research Portal that you believe breaches copyright or violates any law, please contact openaccess@qub.ac.uk. 


\title{
Surface plasmon resonance biosensing: approaches for screening and characterising antibodies for food diagnostics
}

\author{
Yakes BJ ${ }^{1}$, Buijs J ${ }^{2, \text { a }}$, Elliott $\mathrm{CT}^{3}$, Campbell $\mathrm{K}^{3 *}$
}

${ }^{1}$ Center for Food Safety and Applied Nutrition, U.S. Food and Drug Administration, 5100

Paint Branch Parkway, College Park, Maryland 20740, United States

${ }^{2}$ GE Healthcare Bio-Sciences AB, Björkgatan 30, 75184 Uppsala, Sweden

${ }^{a}$ Current address: Department of Radiology, Oncology and Radiation Science, Uppsala

University, Uppsala, Sweden

${ }^{3}$ Institute for Global Food Security, School of Biological Sciences, Queen's University

Belfast, David Keir Building, Stranmillis Road, Belfast, UK BT95AG

* Corresponding author:

Dr Katrina Campbell

Institute for Global Food Security

School of Biological Sciences

Queen's University Belfast

David Keir Building

Stranmillis Road

Belfast

BT95AG

Tel: 0044 (0) 2890976535

Fax: 0044 (0) 2890976513

Keywords: surface plasmon resonance, antibody, biosensor, domoic acid, marine toxin, shellfish 


\section{Abstract}

Research in biosensing approaches as alternative techniques for food diagnostics for the detection of chemical contaminants and foodborne pathogens has increased over the last twenty years. The key component of such tests is the biorecognition element whereby polyclonal or monoclonal antibodies still dominate the market. Traditionally the screening of sera or cell culture media for the selection of polyclonal or monoclonal candidate antibodies respectively has been performed by enzyme immunoassays. For niche toxin compounds, enzyme immunoassays can be expensive and / or prohibitive methodologies for antibody production due to limitations in toxin supply for conjugate production. Automated, selfregenerating, chip-based biosensors proven in food diagnostics may be utilised as rapid screening tools for antibody candidate selection. This work describes the use of both single channel and multi-channel surface plasmon resonance (SPR) biosensors for the selection and characterisation of antibodies, and their evaluation in shellfish tissue as standard techniques for the detection of domoic acid, as a model toxin compound. The key advantages in the use of these biosensor techniques for screening hybridomas in monoclonal antibody production were the real time observation of molecular interaction and rapid turnaround time in analysis compared to enzyme immunoassays. The multichannel prototype instrument was superior with 96 analyses completed in 2 hour compared to 12 hours for the single channel and over 24 hours for the ELISA immunoassay. Antibodies of high sensitivity, $\mathrm{IC}_{50}$ 's ranging from 4.8 to $6.9 \mathrm{ng} / \mathrm{mL}$ for monoclonal and 2.3 to $6.0 \mathrm{ng} / \mathrm{mL}$ for polyclonal, for the detection of domoic acid in a 1 minute analysis time were selected. Although there is a progression for biosensor technology towards low cost, multiplexed portable diagnostics for the food industry, there remains a place for laboratory-based SPR instrumentation for antibody development for food diagnostics as shown herein. 


\section{Introduction}

Awareness of human exposure to a wide range of contaminants through the diet, originating from anthropogenic, natural sources and fraudulent practices along the food supply chain has been heightened with increasing media attention and consumer cognizance. The food supply chain can become contaminated at various points from environment to farm to fork by bacteria, viruses or chemicals present in the environment; the improper use of agrichemicals such as antibiotics and pesticides; the illegal use of growth promoting compounds in animal production; by-products of food processing techniques; and naturally occurring toxins such as phycotoxins and mycotoxins. Food contamination can cause serious acute and chronic health effects resulting in economic and political repercussions with subsequent "food scares" and recalls of products (An et al., 2007; Chen, 2009; Gossner et al., 2009; Holt et al., 1993; Hoogenboom et al., 2015; Lewis et al., 2005; McKay and Scharman 2015; Salleras et al., 1995). In order to monitor food for contamination and to ensure that unacceptable levels do not enter the human food chain, it is imperative that products are subjected to scrutiny, in real time at critical control points in the chain, and with respect to their safety in an efficient and rapid manner.

In recent years, advances in biosensor and nanotechnology for diagnostics have offered solutions, albeit mostly as research tools in portable, multiple analyte diagnostics for small numbers of samples. Relatively expensive biosensor technology (e.g., $\geq \$ 100 \mathrm{~K}$ USD) for food analysis as a screening tool that is restricted to the laboratory setting is generally no longer deemed as cost-effective in comparison to the advances in state-of-the art confirmatory mass spectrometry methods for multiple analytes. These biosensors tend to be only suitably costeffective when they have the ability to efficiently analyse a large number of samples for the presence of multiple chemical contaminants in food matrices with a relatively short turnaround time (McGrath et al., 2012). Additionally, biosensors may be used as an 
alternative to mass spectrometry as a way of diversifying resources and skills in a routine analytical laboratory, but employing both technologies still remains an innovative challenge. Advances over the past two decades have led to the manufacture of a range of instrumentation employing a variety of detection principles. Modern biosensors offer the ability to be portable devices for regulatory bodies and the food industry alike to verify the safety and quality of products intended for human consumption along the food supply chain. It is expected that biosensors will have added advantages over traditional technologies, since they combine the high affinity of the biochemical interactions, resulting in high sensitivities and low limits of detection, with the possible miniaturisation, "point-of-use" portability and automation which make them interesting for in situ monitoring (Campas et al., 2007). Importantly, as biosensors operate on the principle of measuring a biomolecular interaction of two components on a surface, the key component for food analysis still remains the biorecognition element for the interaction and detection with the target contaminant. Polyclonal antibodies, and more recently monoclonal antibodies that reduce the use of animals, still tend to be the most suitable biorecognition elements in commercial immunodiagnostics for food analysis. For the production and characterization of biorecognition elements, the use of a laboratory based biosensing instrument that operates with a high degree of automation, user friendliness, accuracy and precision with real-time analysis is a vital tool for the robust screening and characterization of antibody binding and matrix performance.

Surface plasmon resonance (SPR) biosensor technology has been the most successful immunosensor to date for food analysis and is primarily employed in a laboratory setting. SPR biosensors are affinity, optical sensors where the signal is based on measuring bindinginduced changes in refractive index and this platform thus allows for label-free, real-time analysis (Figure1). Depending on SPR response to the binding of analytes to a surface, an 
analyte can be detected with a direct, sandwich, or inhibition assay. For small analytes (molecular weight $<1000 \mathrm{Da}$ ), an inhibition assay is often used, where small analytes are premixed with antibodies and unbound antibody sites are captured by the small analytes immobilized on a sensor surface (Yu et al., 2005). This approach has been used widely with SPR biosensors for the detection of aquatic toxins (Campbell et al., 2007; Campbell et al., 2013; Devlin et al., 2014; Fonfria et al., 2007; Garibo et al., 2014; Reverte et al., 2015; Yakes et al., 2011; Yakes et al., 2015). Variations in SPR technology is available with different capabilities in analysis due to the utilisation of single or multiple flow channels (Figure 1). Therefore, SPR biosensor technology enables simultaneous observations of molecular interactions on a surface containing multiple channels offering multiplexed evaluations in a single analysis (Campbell et al., 2011; McNamee et al. 2013; Campbell et al., 2014).

In this research, a Biacore SPR high throughput prototype instrument was employed for effective multiplexed analysis for evaluation of the marine toxin, antibody interaction. The system is designed primarily for rapid, simultaneous screening of multiple ligands (up to 16) by employing a $4 \times 4$ format with four $0.6 \mathrm{~mm}^{2}$ flow cell areas that each contain four SPR sensing spots. This flexible, multichannel format enables assays with either multi-ligand or multi-sample focuses. When a Series S CM5 chip with 16 immobilised ligands is docked, four independent parallel flow cells are formed by the sensor chip pressing against moulded channels on the integrated microfluidic cartridge (IFC), and the response is measured from four detection spots in each flow cell (Campbell et al., 2011). Variation in assay design offers alternative approaches for antibody selection, characterisation and target analysis which may be extremely beneficial when the target analyte is expensive or difficult to source (Campbell et al., 2014; Yakes et al., 2014).

Marine biotoxins are an exemplar case whereby the development of rapid methods including antibody-based assays have been restricted due to the limitations in and relatively expensive 
costs of many toxins. In order to investigate SPR biosensor technology for characterizing antibodies to small-molecule toxins, the cost-effective and easily obtainable domoic acid (DA) toxin is used as a model compound in this study. This neurotoxin is renowned to cause amnesic shellfish poisoning (ASP) illness in humans (Iverson and Truelove, 1994; Lelong, 2012; Scholin, 2000) and is predominately found in bivalve shellfish that filter feed on toxin producing diatom of the genus Pseudonitzschia. Thereby, shellfish are regulated with a limit of $20 \mu \mathrm{g}$ DA per gram of tissue in the United States and European Union (US FDA, 2012 and EC 2002/226/EC), and monitoring from both a public health perspective and the protection of the industry brand from toxic recalls is vital. Recent events, including the November 2015 closure of U.S. West Coast Dungeness crab harvesting due to high levels of DA in the waters and accumulation in the crabs (C\&EN 2015), highlight the need for appropriate, rapid detection methods.

To this end, this study aims to demonstrate the (1) development of robust methods for antibody production for a small molecular weight toxin, (2) use of SPR biosensor technologies for antibody screening and selection and (3) investigate the use of a commercial, multi-channel SPR instrument (Biacore T100) for toxin immunoassay development and detection in complex matrices. While this work focuses on the model system of DA in shellfish matrices, the protocols discussed herein should have applicability to a large number of antibody/analyte systems. 


\section{Materials and Methods}

\section{Instrumentation}

An optical SPR Biosensor system (Biacore Q) and a high throughput multichannel prototype instrument (Campbell et al., 2011) with Control and BIAevaluation software 4.1 were obtained from Biacore AB, GE Healthcare (Uppsala, Sweden). For additional assays, a fourchannel SPR instrument (Biacore T100, GE Healthcare) was employed and controlled via Biacore T100 Control software with evaluation via Biacore T100 Evaluation software. Further data processing was performed with GraphPad Prism 5 (La Jolla, CA).

\section{Materials}

Biacore Q CM5 and Series S CM5 sensor chips, HBS-EP and HBS-EP+ buffers and amine coupling kits were obtained from Biacore AB (Uppsala, Sweden). Domoic acid (DA), 1ethyl-3-(3-dimethylaminopropyl) carbodiimide hydrochloride (EDC), N-hydroxysuccinimide (NHS), bovine thyroglobulin (BTG), 2-(N-morpholino)ethanesulfonic acid (MES), 2,2'(ethylenedioxy)bis(ethylamine), L-glutamic acid (GA), L-glutamine $\left(\mathrm{GluNH}_{2}\right)$, kainic acid monohydrate (KA), aspartic acid (AA) and sodium acetate were purchased from SigmaAldrich Company Ltd. (Dorset, UK; St. Louis, MO, USA). The Quil A was from Invivogen (France) while the Pam3Cys-Ser(Lys)4-OH (PCSL) was acquired from EMC Microcollections, GmbH, (Germany). Isotyping kits (Isostrip) were obtained from Roche (UK). Cell culture reagents were obtained from Invitrogen (UK). Borate buffer was procured from Pierce (Thermo Fisher Scientific, Rockford, IL, USA). Tetrodotoxin (TTX, Sankyo Co Ltd., Tokyo, Japan), saxitoxin (STX, National Institute of Standards and Technology (NIST), Gaithersburg, MD, USA), and okadaic acid (OA, National Research Council Canada, Ottawa, Ontario) were employed in cross-reactivity studies. All solvents were of LC grade and were obtained from Rathburn, Walkerburn, Strathclyde, UK. 


\section{Protein Conjugate Synthesis}

Domoic acid was employed as the model small molecular weight compound to demonstrate the capability of the antibody production and instrumentation. Antibodies were raised to domoic acid, bovine thyroglobulin (BTG) protein conjugate. In brief, EDC (11.6 mg) and NHS (10.6 mg) in MES buffer were added to a solution of DA in $1.0 \mathrm{~mL}$ water and mixed for $15 \mathrm{~min}$ at room temperature. BTG $(50 \mathrm{mg})$ was then added to the activated DA solution. The reaction mixture was incubated overnight at room temperature before purification by $24 \mathrm{hr}$ dialysis against saline (0.15 M sodium chloride). The purified immunogen was diluted with saline to a final concentration of $1 \mathrm{mg} / \mathrm{mL}$ protein and stored at $-20{ }^{\circ} \mathrm{C}$ until used. Domoic acid, horse radish peroxidase (DA-HRP) was prepared as the reporter for ELISA in a similar manner as the BTG protein conjugate for immunisations.

\section{Antibody Production}

Polyclonal antibodies were raised in rabbits by subcutaneous injection with $0.2 \mathrm{mg}$ of the DA immunogen emulsified with Freund's complete adjuvant. Booster injections $(0.2 \mathrm{mg}$ of immunogen emulsified with Freund's incomplete adjuvant) were then administered on a fortnightly basis for 2 boosters and monthly for a further 3 booster immunisations. Test bleeds were collected ten days after each booster injection and monitored for the presence of antibodies by the SPR sensor. The antiserum was harvested 28 days after the final booster and stored frozen at $-20{ }^{\circ} \mathrm{C}$ until required.

For the production of monoclonal antibodies a balb/c mouse was immunised with $0.02 \mathrm{mg}$ of immunogen emulsified with Quil A for two immunisations on day 0 and 14 . Three further booster immunisations ( $0.02 \mathrm{mg}$ of immunogen emulsified with the adjuvant $\mathrm{Pam}_{3} \mathrm{Cys}-\mathrm{Ser}-$ $\left.(\text { Lys })_{4}(\mathrm{PCSL})\right)$ were then administered on a monthly basis. Test bleeds were collected ten days after each booster injection and monitored for the presence of antibodies by the SPR 
sensor. Three days after the fifth immunisation the mouse was sacrificed, and the spleen was removed for fusion with an SP2 myeloma cell line to produce monoclonal antibodies (Galfre and Milstein, 1981). All protocols for antibody production performed using animals were conducted in accordance with a licence issued by the Department of Health, Social Services and Public Safety in Northern Ireland, UK under the animal scientific procedures Act 1986.

\section{Biosensor Chip Production}

Domoic acid was immobilised onto the CM5 surface of the sensor chip (Figure 2). Briefly, the chip surface was activated by contact with $50 \mu \mathrm{L}$ of a 1:1 mixture of $0.4 \mathrm{M}$ EDC: $0.2 \mathrm{M}$ NHS for $20 \mathrm{~min}$. The reactants were removed and $50 \mu \mathrm{L}$ of 2,2'(ethylenedioxy)bis(ethylamine) was added and allowed to remain in contact with the sensor chip surface for $1 \mathrm{hr}$; the chip surface was then washed with deionised water prior to the addition of $50 \mu \mathrm{L}$ of $1 \mathrm{M}$ ethanolamine solution for 20 mins. EDC (1.5 mg) and NHS $(0.9 \mathrm{mg})$ were dissolved in $50 \mu \mathrm{L}$ pH 4.7 MES buffer. This mixture $(50 \mu \mathrm{L})$ was added to $250 \mu \mathrm{L}$ of 2 $\mathrm{mg} / \mathrm{mL} \mathrm{DA}$ in water. An aliquot $(50 \mu \mathrm{L})$ of this reactive mixture was added to the chip surface and allowed to react overnight. The chip surface was washed repeatedly with deionised water, dried using a stream of nitrogen gas and stored desiccated at $+4{ }^{\circ} \mathrm{C}$ when not in use.

For the Biacore T100 instrument, a partial in-instrument and partial on-bench coupling method was used. Specifically, the Biacore amine kit, standard amine wizard protocol, and $\mathrm{pH} 8.5,50 \mathrm{mM}$ borate buffer were used to link 2,2'-(ethylenedioxy)bis(ethylamine) to flow cells 2-4 with flow cell 1 left as a reference surface (no coupling). Following ethanolamine inactivation, the sensor chip was removed and DA was coupled to the surface in the same manner as described above. After reacting for $15 \mathrm{hr}$, the sensor chip was rinsed/dried/stored following the same procedure as above. 


\section{Comparison of Hybridoma Screening by SPR biosensors and ELISA}

In SPR biosensor analysis, equal volumes of hybridoma supernatant and HBS-EP pH 7.4 were mixed and tested for binding to DA immobilised on the chip surface. For a positive control, the final mouse bleed, at 1:300 in HAT media, was diluted 1:1 with HBS-EP pH 7.4. A negative control was prepared by 1:1 mixing of HAT media with HBS-EP buffer. Samples were injected over the chip surface at a flow rate of $20 \mu \mathrm{L} / \mathrm{min}$ for $1 \mathrm{~min}$ on both the Biacore Q and prototype high throughput Biacore SPR for comparison. The chip surface was regenerated after each sample injection with $50 \mathrm{mM}$ sodium hydroxide at a flow rate of 20 $\mu \mathrm{L} / \mathrm{min}$ for $1 \mathrm{~min}$.

An antigen capture ELISA assay was also utilised for the initial hybridoma screening. In brief, $25 \mu \mathrm{L}$ of hybridoma supernatant were mixed with $75 \mu \mathrm{L}$ of phosphate buffer $\mathrm{pH} 7.2$, and the antibody allowed to immobilise on 96 well Falcon plates overnight at room temperature. The media was tapped out and DA-HRP prepared in $0.1 \%$ BSA solution was added to the plates and incubated at $4{ }^{\circ} \mathrm{C}$ overnight. The plates were washed ten times with ELISA wash solution (0.15 M saline with $0.125 \%$ Tween 20). Subsequently, TMB-E substrate $(100 \mu \mathrm{L})$ was added, the colour development was stopped after 15 min by adding 50 $\mu \mathrm{L}$ of $2.5 \mathrm{M} \mathrm{H}_{2} \mathrm{SO}_{4}$, and the optical densities were read immediately at $450 \mathrm{~nm}$ using a Tecan Safire plate reader.

Controls were included within each assay type alternating between negative and positive. A positive was deemed as such for any sample that gave a signal equal or greater than the final heart bleed positive control, as lower would be interpreted as non-specific binding. Positive binders were further checked for specificity of binding by competition in the assay with and without DA (100 ng/mL), where DA specific binders were characterised by a reduction of signal when DA was present. Both SPR biosensor and ELISA assays yielded first screen 
hybridomas displaying suitable binding and inhibition. These were then cloned twice for single colony selection whereby clones were then selected for antibody production.

\section{Monoclonal Antibody}

On selection of the best monoclonal antibody, the cell line was grown, and antibody was concentrated in cell culture media using a CELLine 1000 bioreactor (IBS Integra Biosciences, UK), followed by purification via affinity chromatography using a protein Gsepharose gel column (MAbTrap Kit). Dialysis of the antibody over 24 hours in $0.15 \mathrm{M}$ saline ( $3 \times 4 \mathrm{~L})$ was performed. The protein concentration and isotyping of each monoclonal antibody was determined at $\mathrm{A}_{280} \mathrm{~nm}$ and using a mouse monoclonal antibody isotyping kit (Roche Diagnostics), respectively.

\section{Biosensor Characterisation of Monoclonal and Polyclonal Antibodies with Biacore $Q$}

Initially, various parameters were investigated in the development of the Biacore Q biosensor assay including: binder dilution, ratio of binder to standard, injection volume, and contact time. The final assay consisted of: 1:200 antibody in HBS-EP mixed with the sample, contact time of $60 \mathrm{~s}$ with $15 \mathrm{~s}$ dissociation, regeneration with $50 \mathrm{mM} \mathrm{HCl}$ with $0.5 \%$ SDS for $60 \mathrm{~s}$, flow rate of $25 \mu \mathrm{L} / \mathrm{min}$, and analysis temperature at $25^{\circ} \mathrm{C}$. Prior to use, the sample chip was conditioned via the regeneration solution for three cycles. The sensitivity of the monoclonal antibody to DA was assessed using the Biacore Q biosensor. A stock solution of DA (1 $\mathrm{mg} / \mathrm{mL}$ ) was prepared and calibrants at $0,1,2.5,5.0,10,25$ and $100 \mathrm{ng} / \mathrm{mL}$ were prepared in pH 7.4 HBS-EP buffer. These working standards were used to produce calibration curves based on dose-response of the biosensor to compare the antibody performance. 


\section{Transferability to a Biacore T100 Assay}

The monoclonal antibody showing the best sensitivity on the Biacore $\mathrm{Q}$ instrument was evaluated in higher-throughput assays for the detection of domoic acid in shellfish on the commercial, Biacore T100 instrument. Previous studies have shown that the Q and T100 instrumentation, while having variations in surface formation and sensor response, allow for ease of method transferability (Haughey et al. 2011). For the Biacore T100 inhibition assay, assay parameters were adjusted to be consistent with the Biacore Q assay as outlined previously. In the Biacore T100 assay, varying dilutions of binder were evaluated to explore the maximum response and sensitivity of the assay.

\section{Cross-reactivity}

The cross-reactivity of seafood toxins that coexist with DA (e.g., TTX, STX, and OA) and compounds that have similar chemical structure to DA (e.g., GA, GluNH ${ }_{2}, \mathrm{KA}$, and AA) were evaluated. Ten-fold dilutions in buffer of $10,000 \mathrm{ng} / \mathrm{mL}$ of each compound down to 0.1 $\mathrm{ng} / \mathrm{mL}$ were analysed with the anti-DA and SPR assay on the Biacore T100. The curves were fit, and cross-reactivity was determined from a comparison of the $\mathrm{IC}_{50}$ values for each toxin curve to the DA standard curve $\mathrm{IC}_{50}$. Additionally, each cross-reactor at $1000 \mathrm{ng} / \mathrm{mL}$ was tested with the addition of $9.9 \mathrm{ng} / \mathrm{mL}$ DA to determine if additive or subtractive effects were present in these mixtures.

\section{Matrix Evaluation}

DA is a known contaminant of shellfish (Tasker 2015). To further develop the assay, shellfish matrices were prepared and spiked with DA to evaluate assay performance. Specifically, a modified NSSP method was used for the preparation of shellfish samples (AOAC Official Method 2006.02). First, $4 \mathrm{~mL}$ of methanol in water $(50 \%(\mathrm{v} / \mathrm{v}))$ was added to $1 \mathrm{~g}$ of 
homogenized shellfish tissue (aliquoted from a pool of 12 homogenized organisms). For the recovery evaluation, $20 \mu \mathrm{g}$ DA ( $20 \mu \mathrm{L}$ of $1 \mathrm{mg} / \mathrm{mL}$ standard) was added to the homogenized tissue, the sample briefly vortex, and then allowed to sit for 2 min prior to addition of the solvent. Following a 1.5 min vortex, each sample was roller-mixed for $30 \mathrm{~min}$ and then centrifuged at $3000 \times \mathrm{g}$ for $10 \mathrm{~min}$ at room temp. The supernatant was decanted and used for further studies with $5 \mu \mathrm{L}$ supernatant added to $1995 \mu \mathrm{L}$ HBS-EP+ for the Biacore T100 assay.

\section{Results and Discussion}

\section{Immunisation Results}

Small molecular weight molecules or haptens such as domoic acid have limited immunogenicity and must be conjugated to a protein carrier to add immunogenicity. Previous studies indicated that the affinity of the produced antibody for the hapten changed according to the protein carrier used in the conjugation (Chu and Huang, 1992; Kawatsu et al 1999). In previous studies monoclonal antibodies for domoic acid have been raised to BSA, OVA, HGG and KLH for the immunization process (Kawatsu et al., 1999; Kania et al 2003; Le berre et al 2006, Tsao et al 2007) with success primarily for those conjugated to BSA and KLH. However, bovine thyroglobulin, an established carrier protein for producing specific antibodies, had not previously been used for DA. In this work, the immunogen DA-BTG successfully produced an immune response in both mice and rabbits with increasing titres observed compared to before immunisation (Figure 3). For the five rabbits over the 6 month period, the trend in increasing response is typical for the immunisation schedule with a slight dip in response following the switch in adjuvant from Freunds complete to incomplete (between months 2 and 3). For the three immunised mice at month four, one mouse (Mouse

2) showed an increase in response and had higher response than the rabbit counterparts and 
was thus selected for a further immunisation prior to harvesting the spleen for the fusion process. Compared to the first monoclonal antibody produced for DA (Kawatsu et al., 1999) this work showed that the conjugation ratio of toxin to protein can be reduced to $50 \%$ and the dose of immunogen to $20 \%$. This may be crucial for other marine toxins when limited supplies of toxin are available for antibody production.

\section{Comparison of Techniques for Hybridoma Screening}

Mouse 2 was selected for fusion, as the titre for this mouse had the highest binding in the titre, SPR assays. The fusion process was successful, and the first line screening of hybridomas for antibodies against DA was compared by single channel Biacore Q biosensor, multiplex prototype SPR sensor, and ELISA. With these methods, 44 hybridomas screened positive by ELISA, 42 by the single channel biosensor and 43 by the multichannel biosensor, although each method had different positive hybridomas. On comparison, 22 out of 919 hybridomas $(2.3 \%)$ screened positive for all methods. Due to the multi spot (4 spots per channel) and four results per sample nature of the Biacore prototype (Campbell et al. 2011), this method offered increased sensitivity and repeatability of selection compared to the single channel Biacore Q. This prototype instrument can screen 96 samples $(4 \times 24)$ in 2 hours from loading of the instrument, whereas the Biacore Q takes over 12 hours for the same number of samples. Additionally, one ELISA plate, due in part to the overnight coating, takes a minimum of two days. Further, the re-usability of the Biacore chips offered 4-fold reduction in the use of toxin compared to the ELISA screening procedure.

This efficiency in analysis time for routine monitoring for shellfish toxins is an advantage that was highlighted in addition to the use of this prototype instrument for the simultaneous, multiplex detection of marine toxins (Campbell et al. 2014). This system can therefore be extremely beneficial if there are large sample numbers to be analysed for the molecular 
interaction with the same target, but it would not be viably cost effective for small sample numbers. For hybridoma screening for antibody selection, this type of multiplexed, prototype instrument is very valuable, as the interactions can still be monitored in real-time and decisions can be made on the same day to proceed with the workload in hybridoma selection processes.

\section{Monoclonal Isotyping via the SPR Biosensor}

Following cloning, three hybridomas from the original Mouse 2 antibody were selected and monoclonal antibodies purified with protein concentrations Mono $1=1.16 \mathrm{mg} / \mathrm{mL}$, Mono $2=$ $0.86 \mathrm{mg} / \mathrm{mL}$, and Mono $3=1.35 \mathrm{mg} / \mathrm{mL}$. On characterisation by isotyping, the heavy and light chains of the antibodies were IgG2a and k, respectively. The calibration curves (Figure 4) and associated figures of merit (Table 1) for the three monoclonal antibodies and five polyclonal (rabbit) antibodies as run on the Biacore Q showed good sensitivity for the detection of domoic acid with an average $\mathrm{IC}_{50}$ at $5.6 \pm 1.2 \mathrm{ng} / \mathrm{mL}$ for the three monoclonal antibodies and $4.2 \pm 1.6 \mathrm{ng} / \mathrm{mL}$ for the five polyclonal antibodies. The sensitivity of the antibodies as assessed in the performance of the SPR biosensor assay was comparable to those used in different systems (Kania et al 2002; Tsao et al 2007) and improved by at least a factor of $>100$ for the monoclonal antibody compared to a previous SPR biosensor assays by other researchers (Le Berre et al 2006). It is important to note that for each of the antibody calibration curves there was a degree of non-specific binding on the chip surface of approximately 75-100 RU as seen in the high concentration binding levels and that the dynamic range for each of the curves varied. For example, Poly 5 has the lowest binding response but a large linear range $\left(13.4 \mathrm{ng} / \mathrm{mL}\right.$ based on $\mathrm{IC}_{80}$ minus the $\left.\mathrm{IC}_{20}\right)$. Poly 3 has a mid-binding response and the smallest linear range $(4.9 \mathrm{ng} / \mathrm{mL})$, whereas Poly 1 has the highest binding response with a mid-range linearity of $7.7 \mathrm{ng} / \mathrm{mL}$. When choosing the best 
antibodies, these elements are taken into account and were utilised to identify Mono 2, as the antibody further studied due to good binding to the DA-chip of approx. 525 response units, $9.7 \mathrm{ng} / \mathrm{mL}$ dynamic range, and longevity of supply and stability due to the monoclonal nature.

\section{Transferability to T100 Biacore}

Domoic acid, surface plasmon resonance assays have been performed by a number of groups, thus setting the stage for rapid, robust immunosensors for DA in shellfish. In Stevens et al., a portable SPR biosensor was developed for detection of DA down to $3 \mathrm{ppb}$ in diluted clam extract with a surface capable of at least 50 regenerations (Stevens, 2007); however, this prototype SPR instrumentation had high standard deviations which could limit the utility for quantification. An immunosensor developed with a polyclonal antibody researched by Traynor et al. on a single-channel instrument allowed for up to 200 sample injections and shellfish DA concentrations compared well with LC-MS results (Traynor, 2006). Additionally, assays in buffer have been developed by a number of groups including those focusing on surface chemistry and assay development (Yu 2005), DA antibody screening (Le Berre, 2006), and novel molecularly imprinted polymer surfaces (Lotierzo, 2004). By employing these newly produced antibodies and designing a robust surface and assay on a commercial instrument, we are advancing biosensor technology to a potentially more broadly applicable platform for detecting DA in shellfish matrices.

As shown, Mono 2 showed marginally better sensitivity on the Biacore Q instrument and was used for the comparison and evaluation on the Biacore T100. When using 50\% 1:200 Ab mixed with the DA solutions, a raw response of $330 \mathrm{RU}$ was observed for $0 \mathrm{ng} \mathrm{DA} / \mathrm{mL}$. For a 90\% 1:200 Ab assay, the raw response was $650 \mathrm{RU}$. Upon normalization to these values, a curve fit via a log (inhibitor) versus response, four parameter fit was obtained (GraphPad 
Prism v.5.02, La Jolla, CA, USA). As expected, and shown in Figure 5, the curve shapes are similar for each antibody percent but are shifted along the x-axis with the dynamic range for $50 \% \mathrm{Ab}$ from 6.0 to $31.2 \mathrm{ng} / \mathrm{mL}$ and that for the $90 \% \mathrm{Ab} 33.1$ to $226.6 \mathrm{ng} / \mathrm{mL}$. Therefore, this approach of increasing the percentage of antibody can be used to desensitise the assay where necessary. Based on the extraction procedure used herein, $12.5 \mathrm{ng} \mathrm{DA} / \mathrm{mL}$ is equivalent to the United States and European Union guidance levels of $20 \mu \mathrm{g} \mathrm{DA} / \mathrm{gram}$ tissue. In order to obtain the best quantitative capability around this level, the $50 \% \mathrm{Ab}$ mixture with an $\mathrm{IC}_{50}$ of $13.7 \mathrm{ng} / \mathrm{mL}$ was used for further assay evaluation. Additionally, this sensor surface for the T100 assay can be used for at least 311 cycles (per flow cell) with a maximum loss of $25 \%$ of the surface activity ( 330 to $\sim 250 \mathrm{RU})$. This signal decrease, however, did not result in a change to the normalized calibration curve, thus highlighting the robust and reusable nature of the SPR assay.

\section{Cross-reactivity}

The potential seafood toxin cross-reactors STX, TTX, and OA as well as the structurally similar GA, GluNH 2 , and AA did not show cross-reactivity to the anti-DA ( $0 \%$ crossreactivity), while kainic acid showed $24 \%$ cross-reactivity in comparison to domoic acid. Additionally, when mixtures of DA plus the cross-reactors were run, there was no significant difference in signal to that of $10 \mathrm{ng} / \mathrm{mL}$ DA alone, except in the case of KA plus DA. This reactivity is solely due to the aforementioned binding of KA to the surface creating additional signal. These effects are not unexpected, as DA and KA molecules are very similar in structure. Additionally, these results potentially indicate that the antibody is most reactive towards this area of the DA molecule. As KA is associated with a natural marine acid present in some seaweed and is not expected to occur with DA in shellfish samples, there should not be concern about false-positives in naturally contaminated seafood samples. 


\section{Matrix Evaluation and Extraction Recovery}

Six matrices were chosen for evaluation, as these could potentially be contaminated with domoic acid: mussels, surfclams, oysters, scallops (gonad and viscera portions), and quahogs. The oysters (16 oz. wild caught with water added) and clams were purchased from a local vendor while the mussels, scallops and quahogs were harvested in 2007 from waters off the New England Coast of the United States and were determined in-house to be DA-free due to being at or below the blank measurement when using an ELISA.

The raw response for the six matrices $(0 \mathrm{ng} \mathrm{DA} / \mathrm{mL})$ and $\mathrm{HBS}-\mathrm{EP}+$ was between 308.2 to 310.3 RU on Day 1 and 283.3 to 296.2 RU on Day 2. The values are slightly different between days, likely due to minor differences in antibody dilution, but are less than $2 \%$ different within a day. When normalized to their respective $0 \mathrm{ng} \mathrm{DA} / \mathrm{mL}$ response, nearly identical overlap of the curves for each matrix are observed (Figure 6). This excellent overlap with the HBS-EP+ curve indicates that there are no obvious matrix effects. As there are no interferences from mussel, clam, oyster, scallop (gonad or viscera), and quahog matrices when using the 1 in 400 dilution necessary to have the action level near the centre of the linear range, there is no need to matrix match for the DA assay. As such, analysis can be significantly streamlined by having a singular buffer curve for quantitation of a variety of shellfish samples. To further evaluate this and determine DA recovery from the shellfish samples, an HBS-EP+ calibration curve was used to back calculate the concentration in the $20 \mu \mathrm{g}$ DA per $1 \mathrm{~g}$ tissue spikes. Each sample was analysed ( $\mathrm{n}=3$ per analysis) in duplicate. These initial studies show promise for this simple extraction method and the use of biosensor assays with this new antibody, as the extraction is efficient for each matrix (76\% to 109\%) as shown in Table 2. Additionally, there was little variation in the day one versus day two measurements as shown in Table 2 where the $\% \mathrm{CVs}$ ranged from 2.01 to $6.45 \%$ for the six 
matrices. This further elucidates the robust nature of the SPR biosensor to yield repeatable results in sample analysis.

\section{Conclusions}

This work illustrated the application of three different SPR optical biosensors (high throughput Biacore prototype, Biacore Q and Biacore T100) in antibody production for their development and characterisation using domoic acid as a model target. The conjugation and immunization protocol developed herein for domoic acid applied lower toxin to protein ratios ( $50 \%$ less than previous methods) and thereby reduced the dose of immunogen by $20 \%$. For antibody development and characterisation, the optical SPR biosensor offered the set-up of a simple assay design for real time evaluation of sensitivity, cross reactivity with structurally related compounds, as well as the effects of different shellfish matrices on the antibodyanalyte interaction. The multichannel biosensors offer enhanced speed for screening for suitable binders during monoclonal antibody selection. The assays developed herein for DA are, to our knowledge, the fastest and most sensitive SPR assays and can be used for over 300 cycles with triplicate measurement per cycle. This study highlights that automated SPR biosensors can be effective tools for antibody characterisation, and these antibodies can then be employed for sensitive, robust DA detection in the diagnostics environment. Methods developed herein can be employed for further development of well-performing antibodies for toxin detection. 


\section{Acknowledgments}

This research was funded in part by the European Commission through the FP7 European projects; MIDTAL, Grant No. 201724, MicroAqua, Grant No. 265409 and the Advanced ASSET project, partly funded through InvestNI and from the European Sustainable Programme 2007-2013 under the European Regional Development Fund (“ERDF”). Thank you to Dr. Stacey DeGrasse for fruitful conversations and Stephen Conrad for maintaining the U.S. FDA/CFSAN seafood sample inventory and to Dr Shauna Devlin for assistance in the monoclonal antibody fusion procedure. 


\section{References}

1. An, Y., Jiang, L.P., Cao, J., Geng, C.Y. \& Zhong, L.F. (2007) Sudan I induces genotoxic effects and oxidative DNA damage in HepG2 cells. Mutation Research-Genetic Toxicology and Environmental Mutagenesis, 627, 164-170.

2. AOAC International (2007) AOAC Official Method 2006.02. Domoic Acid Toxins in Shellfish. Biosense ASP Elisa - a Competitive Direct Enzyme-Linked Immunosorbent Asssay.

3. Campàs, M., Prieto-Simón, B., Marty, J.L. (2007) Biosensors to detect marine toxins: assessing food safety. Talanta, 72, 884-895.

4. Campbell, K., McGrath, T., Sjölander, S., Hanson, T., Tidare, M., Jansson, O., Moberg, A., Mooney, M., Elliott, C., Buijs, J. (2011) Use of a novel micro-fluidic device to create arrays for multiplex analysis of large and small molecular weight compounds by surface plasmon resonance. Biosensors and Bioelectronics, 26, 3029-30

5. Campbell. K., McNamee, S.E., Huet, A.C., Delahaut, P., Vilarino, N., Botana, L.M., Poli, M., Elliott, C.T. (2014) Evolving to the optoelectronic mouse for phycotoxin analysis in shellfish. Analytical and bioanalytical chemistry, 406 (27) 6867-6881.

6. Campbell, K., Stewart, L.D., Doucette, G.J., Fodey, T.L., Haughey, S.A., Vilariño, N., Kawatsu, K., Elliott, C.T. (2007) Assessment of specific binding proteins suitable for the detection of paralytic shellfish poisons using optical biosensor technology. Analytical Chemistry, 79 (15) 5906-5914.

7. Campbell, K., Barnes, P., Haughey, S.A., Higgins, C., Kawatsu, K., Vasconcelos, V., Elliott, C.T. (2013) Development and single laboratory validation of an optical biosensor assay for tetrodotoxin detection as a tool to combat emerging risks in European seafood. Analytical and Bioanalytical Chemistry, 405 (24) 7753-7763.

8. Chemical \& Engineering News, "Neurotoxin scuttles crab season", 93(45), page 8, November 12, 2015

9. Chen, J. (2009) A worldwide food safety concern in 2008 - melamine contaminated infant formula in China caused urinary tract stones in 290,000 children in China. Chinese Medical Journal 122, 243-244.

10. Chu, F.S., Huang, X. (1992) Production and characterization of antibodies against neosaxitoxin. J. AOAC Int. 75, 341-345.

11. Commission Decision of 15 March 2002 establishing special health checks for the harvesting and processing of certain bivalve molluscs with a level of amnesic shellfish poison (ASP) exceeding the limit laid down by Council Directive 91/492/EEC Official Journal L075, 2002, 65-66

12. Devlin, S., Meneely, J.P., Greer, B., Campbell, K., Vasconcelos, V., Elliott, C.T. (2014) Production of a broad specificity antibody for the development and validation of an 
optical SPR screening method for free and intracellular microcystins and nodularin in cyanobacteria cultures. Talanta, 122, 8-15.

13. Fonfría, E.S., Vilariño, N., Campbell, K., Elliott, C., Haughey, S.A., Ben-Gigirey, B., Vieites, J.M., Kawatsu, K., Botana, L.M. (2007) Paralytic shellfish poisoning detection by surface plasmon resonance-based biosensors in shellfish matrixes. Analytical Chemistry, 79 (16) 6303-6311.

14. Garibo, D., Campbell, K., Casanova, A., De La Iglesia, P., Fernández-Tejedor, M., Diogène, J., Elliott, C.T., Campàs, M. (2014) SPR immunosensor for the detection of okadaic acid in mussels using magnetic particles as antibody carriers. Sensors and Actuators, B: Chemical, 190, 822-828.

15. Galfre, G. Milstein C. (1981) Preparation of monoclonal antibodies: strategies and procedures. Methods in Enzymology 72, 3-46

16. Gossner, C. M. E., Schlundt, J., Ben Embarek, P., Hird, S., Lo-Fo-Wong, D., Beltran, J. J. O., Teoh, K. N. \& Tritscher, A. (2009) The Melamine Incident: Implications for International Food and Feed Safety. Environmental Health Perspectives, 117, 1803-1808.

17. Haughey, S.A., Campbell, K., Yakes, B.J.; Prezioso, S.M., DeGrasse, S.L., Kawatsu, K., Elliott, C.T. (2011) Comparison of biosensor platforms for surface plasmon resonance based detection of paralytic shellfish toxins. Talanta 85 (1), 519-526.

18. Holt, D., Harvey, D. and Hurley, R. (1993) Chloramphenicol toxicity, Adverse Drug Reaction Toxicology Review, 12, 83-95.

19. Hoogenboom R, Traag W, Fernandes A, Rose M (2015) European developments following incidents with dioxins and PCBs in the food and feed chain. Food Control 50, $670-683$

20. Iverson, F.; Truelove J. (1994) Toxicology and seafood toxins: domoic acid. Natural Toxins 2, 334-339.

21. Kania M., Kreuzer M., Moore E., Pravada M., Hock B., Guilbault G. (2003) Development of Polyclonal Antibodies Against Domoic Acid for Their Use in Electrochemical Biosensors Analytical Letters 36 (9) 1851-1863

22. Kawatsu K., Hamano Y., Noguchi T (1999) Production and characterization of a monoclonal antibody against domoic acid and its application to enzyme immunoassay. Toxicon 37, 1579-1589

23. Le Berre, M., Kane, M. (2006) Biosensor-Based Assay for Domoic Acid: Comparison of Performance Using Polyclonal, Monoclonal, and Recombinant Antibodies. Analytical Letters 39(8), 1587-1598.

24. Lelong, A.; Hegaret, H.; Soudant, P.; Bates, S.S. (2012) Pseudo-nitzschia (Bacillariophyceae) species, domoic acid and amnesic shellfish poisoning: revisiting previous paradigms. Phycologia 51 (2) 168-216. 
25. Lewis, L., Onsongo, M., Njapau, H., Schurz-Rogers, H., Luber, G., Kieszak, S., Nyamongo, J., Backer, L., Dahiye, A. M., Misore, A., Decock, K., Rubin, C. \& Kenya Aflatoxicosis, I. (2005) Aflatoxin contamination of commercial maize products during an outbreak of acute aflatoxicosis in eastern and central Kenya. Environmental Health Perspectives 113, 1763-1767.

26. Llamas, N, Stewart, L, Fodey, T, Higgins, HC, Velasco, MLR, Botana, Elliott, CT. (2007) Development of a novel immunobiosensor method for the rapid detection of okadaic acid contamination in shellfish extracts. Analytical and Bioanalytical chemistry $389,581-585$

27. Lotierzo, M., Henry, O.Y.F., Piletsky, S., Tothill, I., Cullen, D., Kania, M., Hock, B., Turner, A.P.F. (2004) Surface Plasmon Resonance Sensor for Domoic Acid Based on Grafted Imprinted Polymer. Biosensors and Bioelectronics. 20 (2) 145-152.

28. McGrath, T.F., Elliott C., Fodey T.L. (2012) Biosensors for the analysis of microbiological and chemical contaminants in food. Analytical and Bioanalytical Chemistry 403 (1) 75-92

29. McNamee, S.E., Elliott, C.T., Delahaut, P., Campbell, K. (2013) Multiplex biotoxin surface plasmon resonance method for marine biotoxins in algal and seawater samples. Environmental science and pollution research international, 20 (10) 6794-6807.

30. McKay, C. and Scharman E.J. (2015) Intentional and Inadvertent Chemical Contamination of Food, Water, and Medication Emergency Medicine Clinics of North America, 33 (1) 153-177

31. Salleras, L., Dominguez, A., Mata, E., Taberner, J.L., Moro, I. and salva, P. (1995) Epidemiologic study of an outbreak of clenbuterol poisoning in Catalonia, Spain, Public Health Reports, 110, 338-342.

32. Reverté, L., De La Iglesia, P., Del Río, V., Campbell, K., Elliott, C.T., Kawatsu, K., Katikou, P., Diogène, J., Campàs, M. (2015) Detection of Tetrodotoxins in Puffer Fish by a Self-Assembled Monolayer-Based Immunoassay and Comparison with Surface Plasmon Resonance, LC-MS/MS, and Mouse Bioassay. Analytical Chemistry, 87 (21) 10839-10847.

33. Scholin, C. A.; Gulland, F.; Doucette, G. J.; Benson, S.; Busman, M.; Chavez, F. P.; Cordaro, J.; DeLong, R.; De Vogelaere, A.; Harvey, J.; Haulena, M.; Lefebvre, K.; Lipscomb, T.; Loscutoff, S.; Lowenstine, L. J.; Marin, R.; Miller, P. E.; McLellan, W. A.; Moeller, P. D. R.; Powell, C. L.; Rowles, T.; Silvagni, P.; Silver, M.; Spraker, T.; Trainer, V.; Van Dolah, F. M. (2000) Mortality of sea lions along the central California coast linked to a toxic diatom bloom. Nature 403 (6765), 80-84.

34. Stevens, R.C., Soelberg, S.D., Eberhart, B.T.L., Spencer, S., Wekell, J.C., Chinowsky, T.M., Trainer, V.L., Furlong, C.E. (2007) Detection of the Toxin Domoic Acid from Clam Extracts Using a Portable Surface Plasmon Resonance Biosensor. Harmful Algae 6 (2), 166-174. 
35. Tasker, R.A. (2015) Domoic acid and other amnesic toxins: toxicological profile, p. 116. In: Gopalakrishnakone, P., V. Haddad Jr., W.R. Kem, A. Tubaro, and E. Kim [eds.] Marine and Freshwater Toxins. Springer Science+Business Media Dordrecht, Dordrecht Netherlands.

36. Traynor, I.M., Plumpton, L., Fodey, T.L., Higgins, C., Elliott, C.T., (2006) Immunobiosensor Detection of Domoic Acid as a Screening Test in Bivalve Molluscs: Comparison with Liquid Chromatography-Based Analysis. J. AOAC Int. 89 (3), 868872.

37. Tsao Z.J., Liao Y.C., Liu B.H., Su C.C., Yu F.Y. (2007) Development of a Monoclonal Antibody against Domoic Acid and Its Application in Enzyme-Linked Immunosorbent Assay and Colloidal Gold Immunostrip. Jourmal of Agricultural and Food Chemistry 55 (13) 4921-4927

38. U.S. Food and Drug Administration. Fish and Fisheries Products Hazards and Controls Guidance. Chapter 6: Natural Toxins [Online]. http://www.fda.gov/Food/GuidanceRegulation/GuidanceDocumentsRegulatoryInformati on/Seafood/ucm2018426.htm.

39. U.S. Food and Drug Administration. Bad Bug Book: Handbook of Foodborne Pathogenic Microorganisms and Natural Toxins. Chapter Title: Shellfish toxins (PSP, DSP, NSP, ASP, AZP) [Online] 2012; page 200. http://www.fda.gov/downloads/Food/FoodborneIllnessContaminants/UCM297627.pdf.

40. Yakes, B. J., Prezioso, S., Haughey, S. A., Campbell, K., Elliott, C.T., DeGrasse, S. L. (2011) An improved immunoassay for detection of saxitoxin by surface plasmon resonance biosensors. Sensors and Actuators B Chem. 156 (2), 805-811.

41. Yakes, B. J.; Kanyuck, K. M.; DeGrasse, S. L. (2014) First report of a direct surface plasmon resonance immunosensor for a small molecule seafood toxin. Analytical Chemistry 86 (18), 9251-9255.

42. Yakes, B.J.; Handy, S.M.; Kanyuck, K.M.; DeGrasse, S.L. (2015). Improved screening of microcystin genes and toxins in blue-green algal dietary supplements with PCR and a surface plasmon resonance biosensor. Harmful Algae 47, 9-16.

43. Yu, Q.M., Chen, S.F., Taylor, A.D., Homola, J., Hock, B., Jiang, S.Y. (2005) Detection of Low-Molecular-Weight Domoic Acid Using Surface Plasmon Resonance Sensor. Sensors and Actuator B-Chem. 107(1), 193-201. 
TABLE 1: Figures of merit for the monoclonal (Mono) and polyclonal (Poly) antibodies developed to the DA-BTG conjugate as analysed by the Biacore Q

\begin{tabular}{|c|ccc|ccccc|}
\cline { 2 - 9 } \multicolumn{1}{c|}{} & \multicolumn{7}{c|}{ Domoic Acid Concentration (ng/mL) } \\
\cline { 2 - 9 } \multicolumn{1}{c|}{} & Mono 1 & Mono 2 & Mono 3 & Poly 1 & Poly 2 & Poly 3 & Poly 4 & Poly 5 \\
\hline IC20 & 1.6 & 1.6 & 2.2 & 1.7 & 0.9 & 0.7 & 1.5 & 1.8 \\
IC50 & 5.0 & 4.8 & 6.9 & 4.7 & 2.8 & 2.3 & 5.1 & 6.0 \\
IC80 & 11.8 & 11.3 & 16.6 & 9.4 & 6.9 & 5.6 & 12.8 & 15.2 \\
\hline
\end{tabular}

TABLE 2. Recovery analysis from shellfish matrices and the SPR assay. Concentration day one (Conc 1) is back calculated from GraphPad Prism and an HBS-EP+ curve ( $\mathrm{N}=3$ for all measurements) and similarly repeated on day 2 for Conc 2 .

\begin{tabular}{|c|c|c|c|c|c|c|c|c|c|c|}
\hline \multirow[b]{2}{*}{ Sample } & \multicolumn{5}{|c|}{ Calculated (ng/mL) } & \multirow{2}{*}{$\begin{array}{c}\text { 1g } \\
\text { Tissue }\end{array}$} & \multirow{2}{*}{$\begin{array}{c}\mathrm{mmL} \\
\text { Extract } \\
\text { Volume }\end{array}$} & \multirow[b]{2}{*}{$\begin{array}{c}\mu \mathrm{g} / \mathrm{g} \\
\text { tissue }\end{array}$} & \multirow[b]{2}{*}{ Spiked } & \multirow[b]{2}{*}{$\begin{array}{c}\% \\
\text { Recovery }\end{array}$} \\
\hline & Conc 1 & Conc 2 & AVG & SD & $\% \mathrm{CV}$ & & & & & \\
\hline Clam & 8.54 & 9.14 & 8.84 & 0.42 & 4.77 & 1.02 & 4.4 & 15.3 & 20 & 76 \\
\hline Mussel & 11.7 & 12.82 & 12.26 & 0.79 & 6.45 & 1.02 & 4.5 & 21.6 & 20 & 108 \\
\hline Oyster & 8.54 & 8.81 & 8.68 & 0.19 & 2.17 & 0.99 & 4.4 & 15.4 & 20 & 77 \\
\hline Viscera & 9.87 & 10.52 & 10.2 & 0.46 & 4.50 & 1.00 & 4.4 & 17.9 & 20 & 90 \\
\hline Gonad & 10.58 & 10.89 & 10.73 & 0.22 & 2.01 & 0,99 & 4.4 & 19.1 & 20 & 95 \\
\hline Quahog & 12.49 & 13.23 & 12.86 & 0.52 & 4.08 & 1.01 & 4.3 & 21.9 & 20 & 109 \\
\hline
\end{tabular}




\section{FIGURES}

Figure 1: Surface plasmon resonance (SPR) technology measures light reflection from the side of the chip opposite the flow channel. Upon antibody-toxin interaction at the chip surface, the change in reflected light angle (I to II) is detected. Each of the biosensors has different capacity for the simultaneous determination of toxin interaction on the surface due to the number of flow channels and detection points on each channel.

\section{SPR Optical Detection Unit}

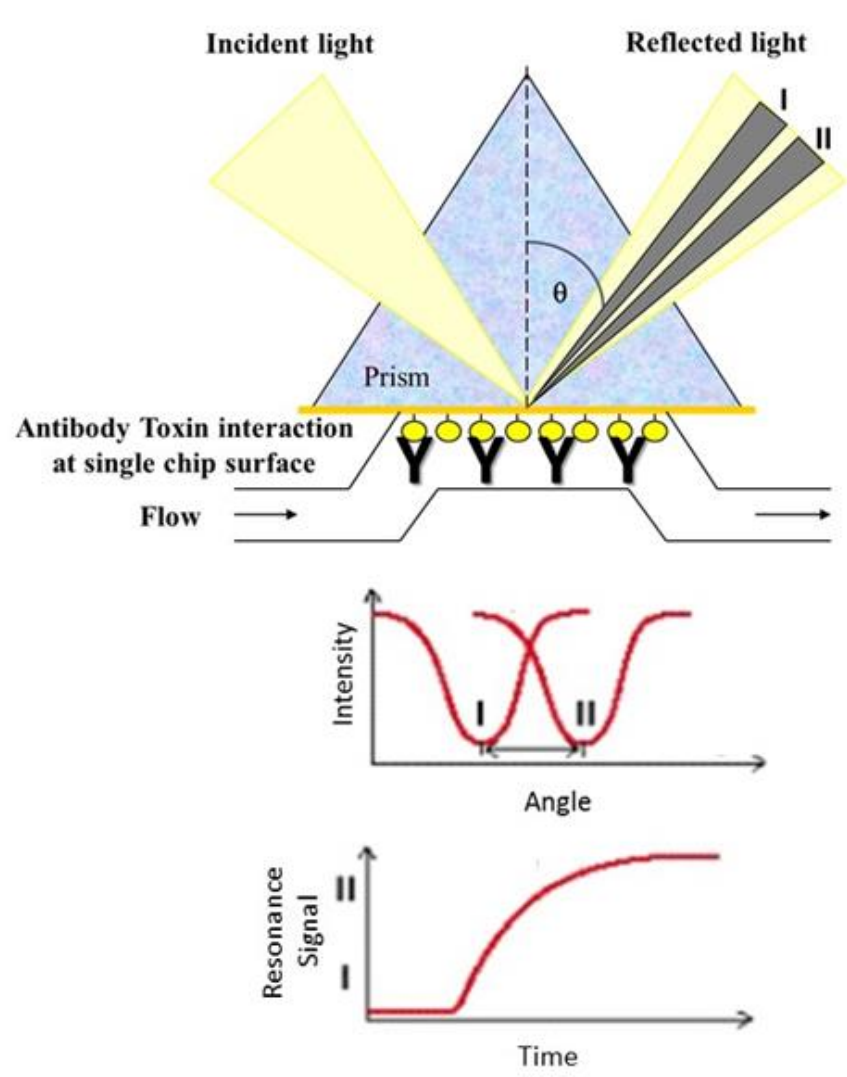

Biacore Q - Single Flow Channel

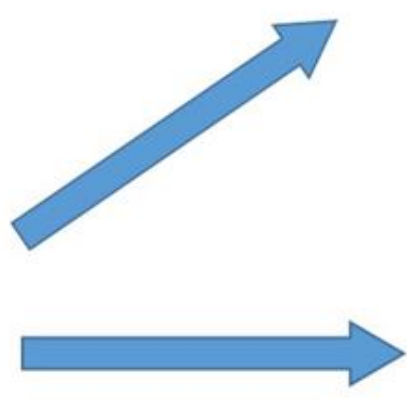

Flow

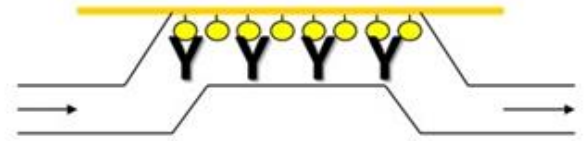

Biacore T100 - Four Flow Channels

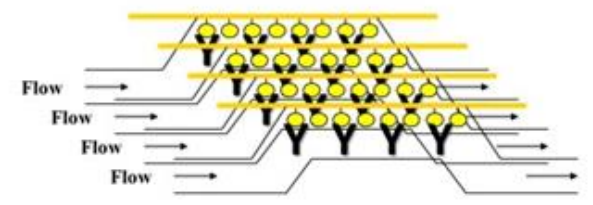

Prototype HTS - Four Flow Channels 16 interaction detection spots

FC

FC2

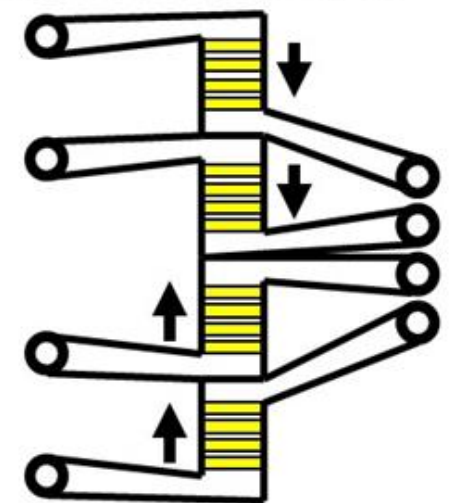


Figure 2: Chip surface chemistry for the immobilisation of domoic acid onto the surface of CM5 SPR biosensor chips.

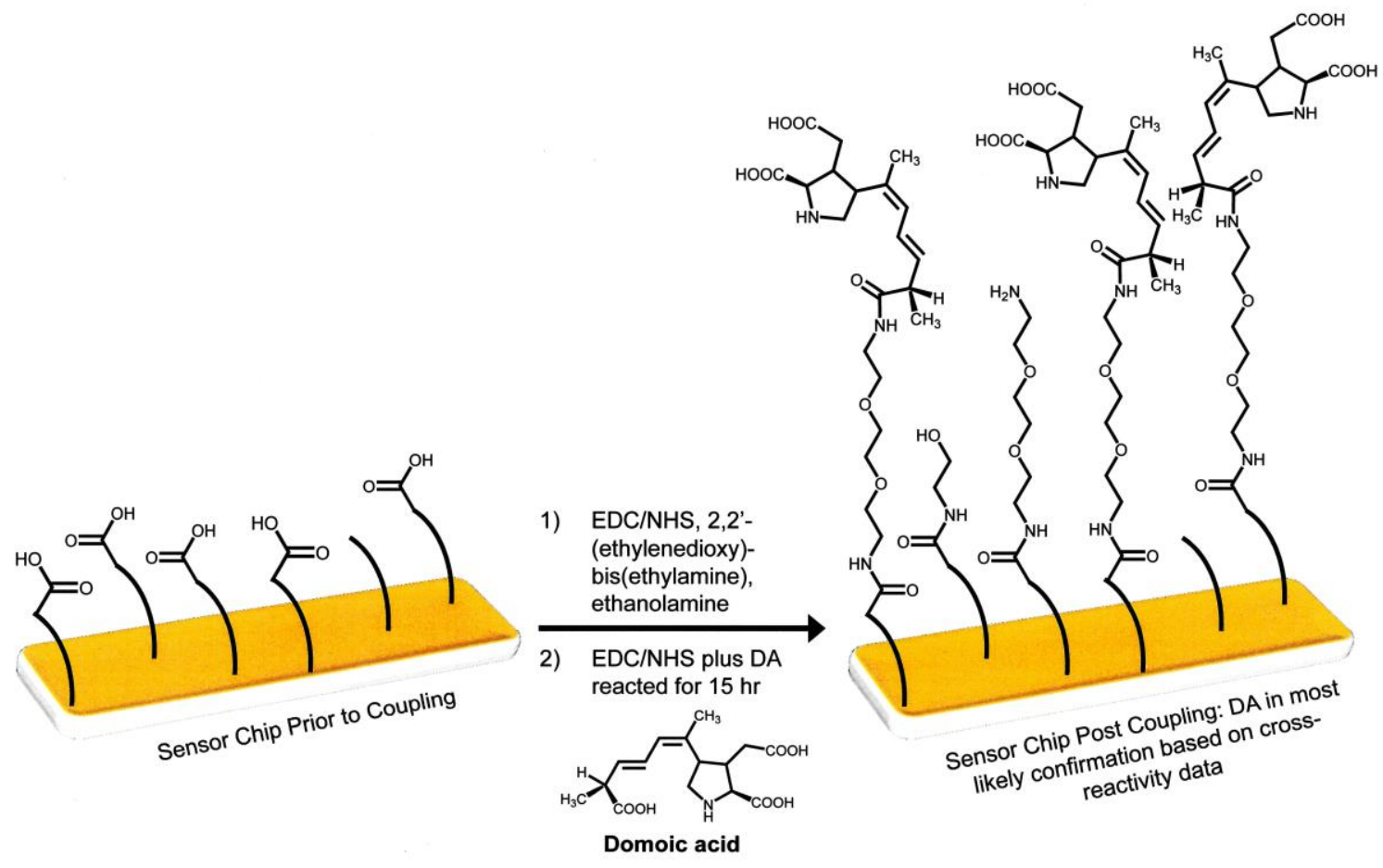


Figure 3: Evaluation of antibody titres for mice and rabbits each month over the immunisation period illustrated by the SPR response value obtained by the analysis of each sera at 1 in 50 dilution mixed in HBS-EP buffer each month.
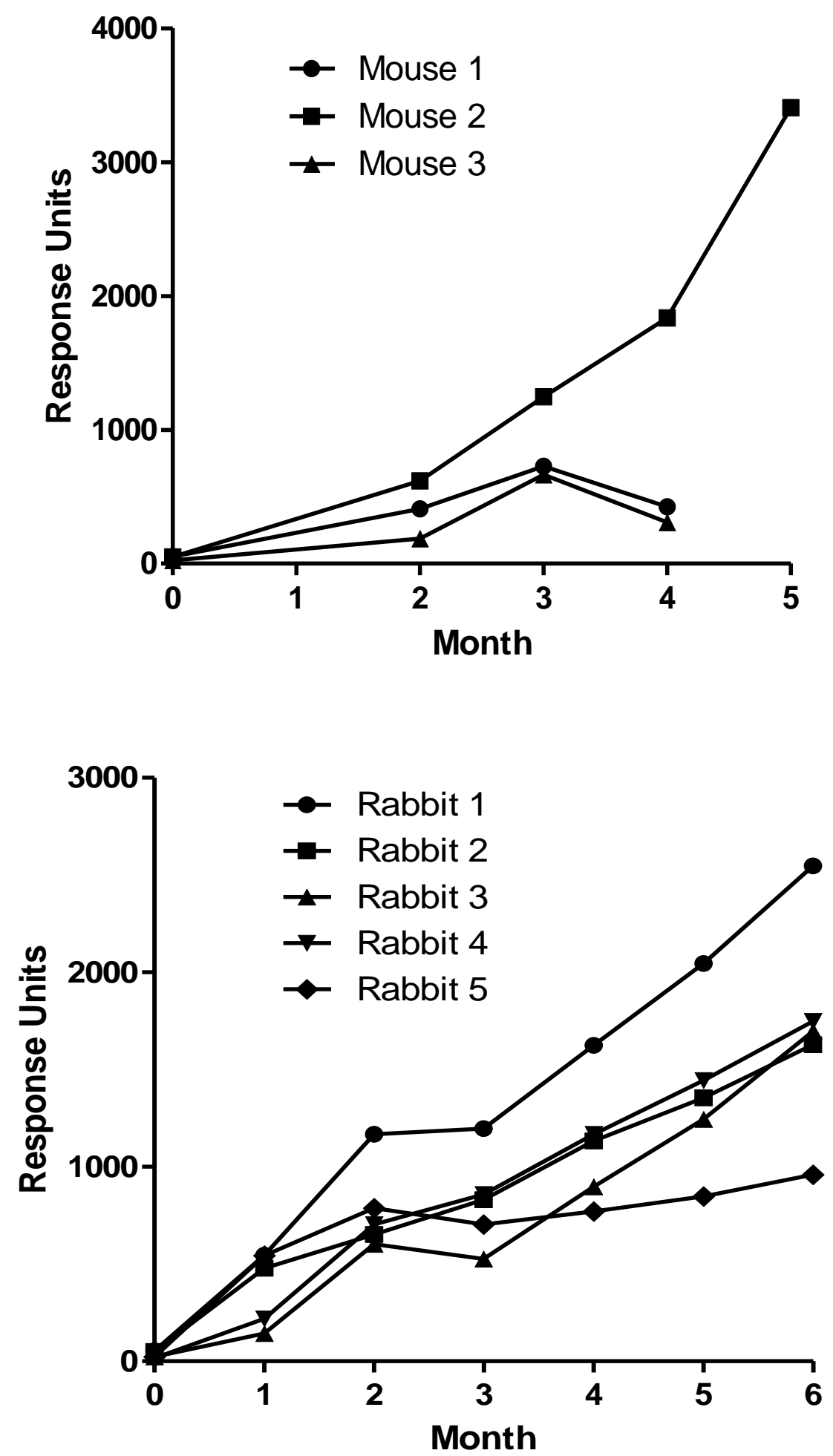
Figure 4: Concentration analysis curves of response versus concentration for mouse derived monoclonal antibodies and each rabbit polyclonal antibody $(1-5)(\mathrm{n}=2$ for each data point with standard deviation less than the data point.)
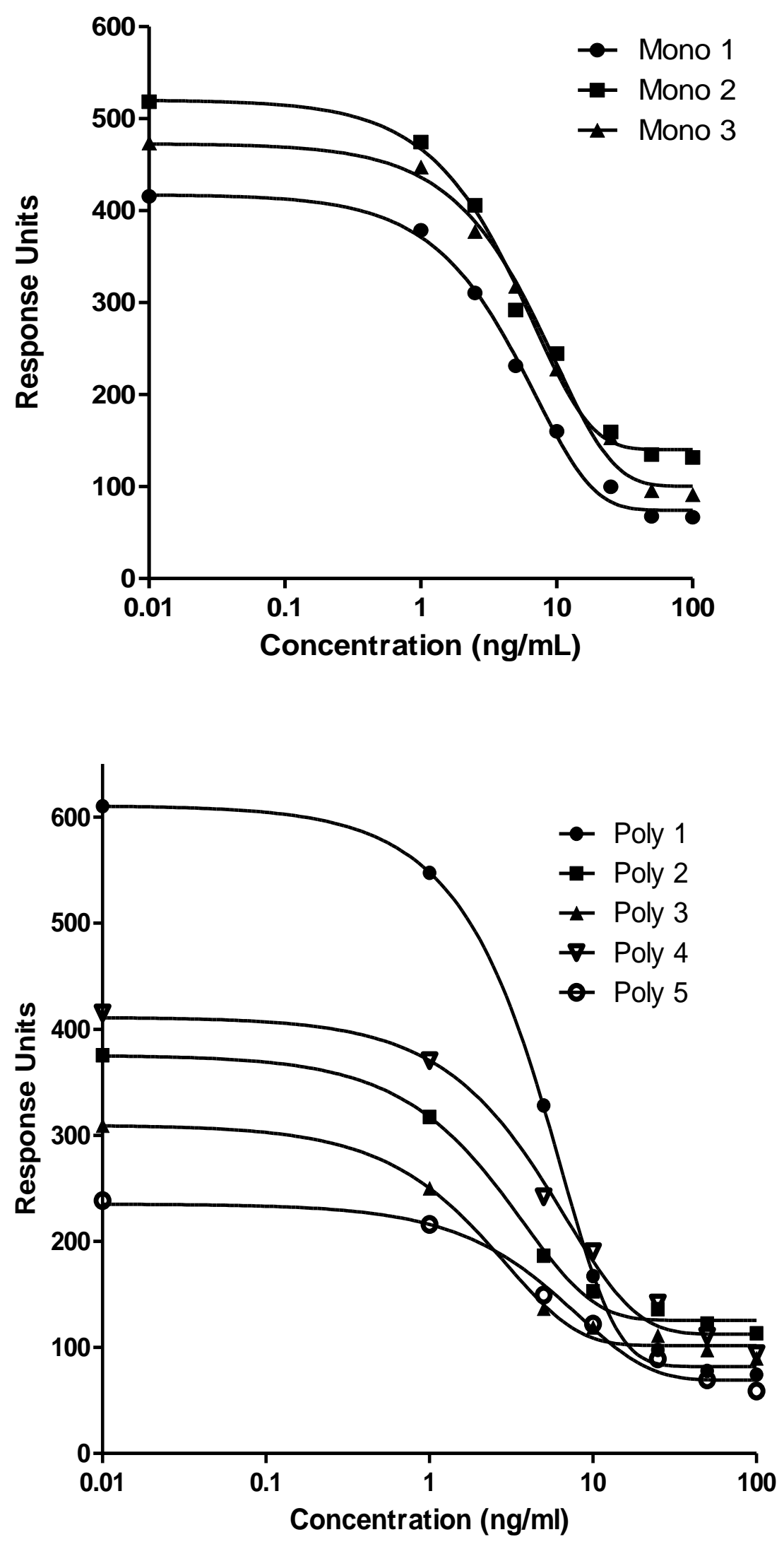
Figure 5. Biacore T100 calibration curves of DA inhibition assay with new DA binding protein (Mono 2). ( $\mathrm{n}=3$ for each data point with standard deviation less than the data point.)

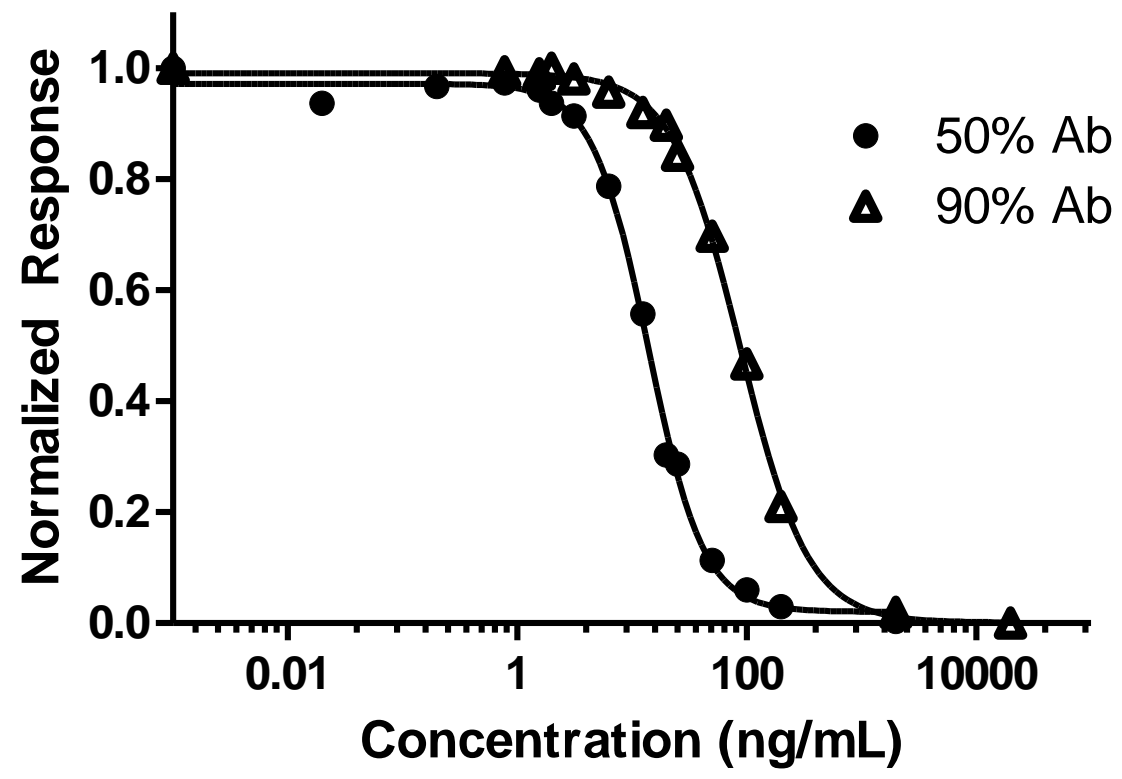

Figure 6. Biacore T100 calibration curves for DA-spiked shellfish matrices in comparison to DA-spiked buffer ( $n=3$ for each data point with standard deviation less than the data point.)

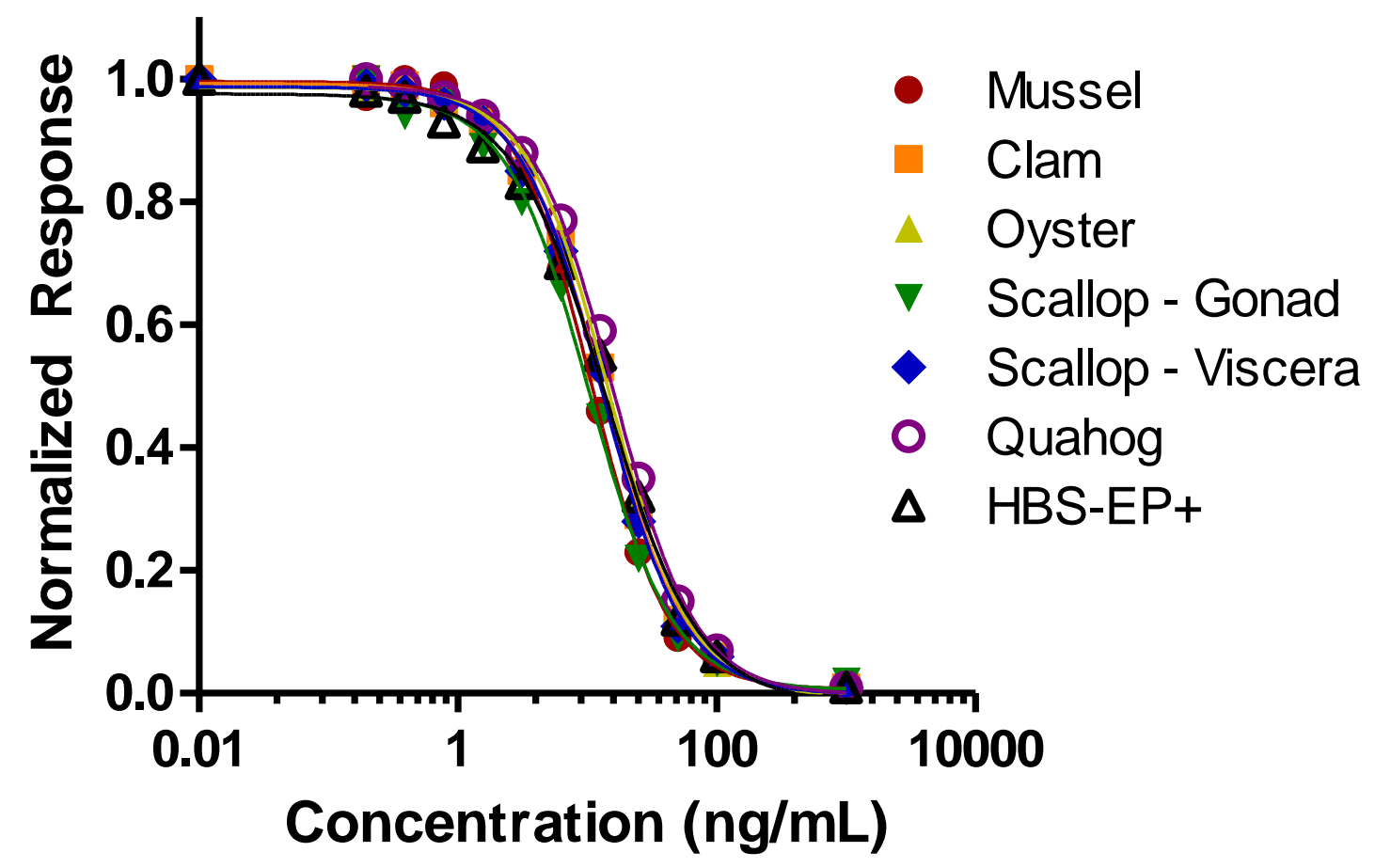

